\title{
Gerhard Aschinger* \\ An Economic Analysis of the East Asia Crisis
}

\begin{abstract}
Since the summer of 1997, the East Asian "tiger" nations have suffered an unprecedented bout of weakness, plunging what had been vigorously expanding economies into a deep crisis. A number of domestic economic problems joined forces with turbulence on the foreign exchanges to generate a crisis of confidence on a grand scale. The crisis was triggered off by fundamental imbalances, with a key role being played by the "moral hazard" effect: domestic enterprises had been backed by implicit state guarantees, and it was always assumed that the IMF would assist if necessary. Then a destabilizing wave of speculation ran through the financial markets, pushing even countries with sound economic structures into difficulties.

This article highlights the sequence of developments in the East Asian crisis, providing an economic explanation of the phenomenon.
\end{abstract}

$\mathrm{T}$ he South-East Asian countries of Thailand, Malaysia, Singapore, Indonesia and the Philippines had been enjoying a veritable economic upsurge for over ten years, with high real rates of growth (see Figure 1). The foundations for the East Asian economic miracle had been laid by low wages, by highly motivated people, and by liberal economic policies which also opened up domestic financial and capital markets to foreign investors.

For many years Thailand, with its liberal legal environment for investors and its idea of making the exporting sector the engine of economic development, was widely regarded as a model for other developing countries to follow. In the light of an impressive export performance and high rates of growth, an ever-increasing inflow of foreign capital came into Bangkok once its financial markets had been deregulated in the early 1990s. That inflow of funds was further spurred on both by relatively high interest rates and the pegging of the Thai baht to the US dollar, allowing the currency to be judged as stable. However, these substantial volumes of capital imports were increasingly made up not so much of the long-term funds used to invest in real capital as of short-term portfolio investment which responds sensitively to new information.

\footnotetext{
- University of Fribourg, Switzerland
}

The major inflow of foreign exchange led to pronounced domestic credit expansion, some of which ended up in the property sector. Financial institutions that lend long while doing a lot of their borrowing on a short-term basis are liable to run into liquidity problems if their creditors start to pull out their money due to distrust. There were more than 90 finance companies operating in Thailand, more than half of which have now had to be liquidated. These companies, which had been inadequately supervised by government authorities, had been particularly careless in their lending to the property sector.

Similarly, a large amount of borrowing went into funding private consumption, with not enough financial resources going into capital investment to enhance productivity. Thailand's balance of payments soon showed a drastic increase in the current account deficit, as stagnating exports were outweighed by a high level of imports and by the interest payments on foreign debt (see Figure 2). Recessionary tendencies and slack growth in many of the main industrial

\footnotetext{
- The function of financial intermediaries is to provide long-term credit even if their debt consists mainly of short-term deposits. According to the central limit theorem the liquidity risk can be substantially reduced by pooling. That is why banks will hold a small percentage in cash under normal circumstances. The risk of bank runs, however, cannot be excluded. Even solvent financial intermediaries may be involved in a self-fulfilling panic. Deposit insurance will help to prevent sudden deposit withdrawals but may lead to moral hazard of the intermediary.
} 


\section{Figure 1}

\section{Rates of real GDP Growth in East Asian Countries, 1991-1996}

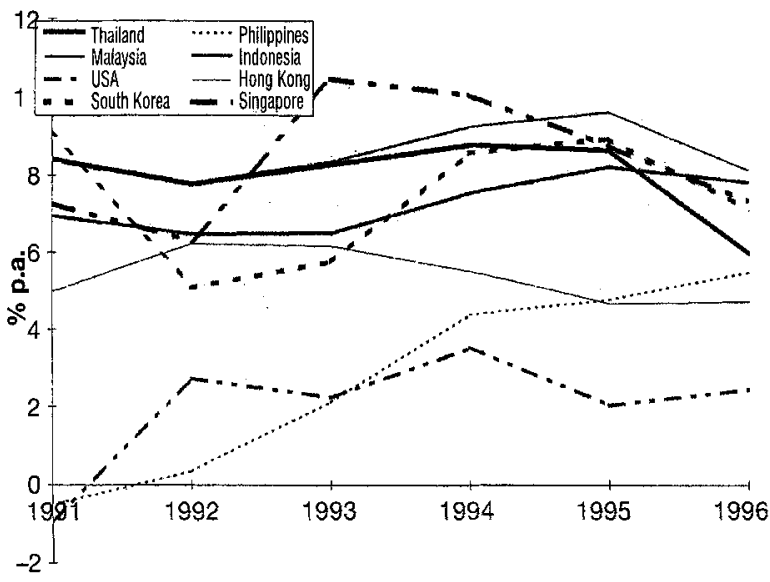

countries (especially Japan and European countries) damped down the demand for export goods. At the same time, rising wage levels in Thailand led to intensified competition with low-wage countries such as the People's Republic of China and Vietnam. Thailand's exports chiefly include textile products, electronic articles and computer components.

The serious financial crisis in Thailand which began in the property sector reached a peak in spring 1997, quickly spreading to the rest of the economy. Massive speculation against the Thai baht was met at first by a major support drive mounted by the Bank of Thailand, which injected more than $\$ 4$ billion into the market during May in a bid to stave off the attacks being mounted by hedge funds and other market players. The "de facto" peg to the US dollar finally had to be abandoned on 2nd July 1997, and the baht immediately depreciated by $17 \%$ against the dollar. ${ }^{2}$

Thailand's crisis had its roots at home. The rapid increase in foreign debt, which had reached $\$ 90$ billion by July 1997, growing lending to the property sector, the use of borrowing to finance consumer spending while productive investment in industry was neglected, coupled with the intensified competition from low-wage producers and a falling demand for export products all fuelled the current account deficit. The speculation against the baht on the foreign exchanges was thus based on fundamentals and did not, in the first instance, amount to speculation of a destabilizing nature. ${ }^{3}$ Other aspects which need to be borne in mind when judging this crisis are the numerous changes taking place among the country's
Figure 2

\section{Current Account Balances in East Asian Countries, as a proportion of GDP, 1990-1996}

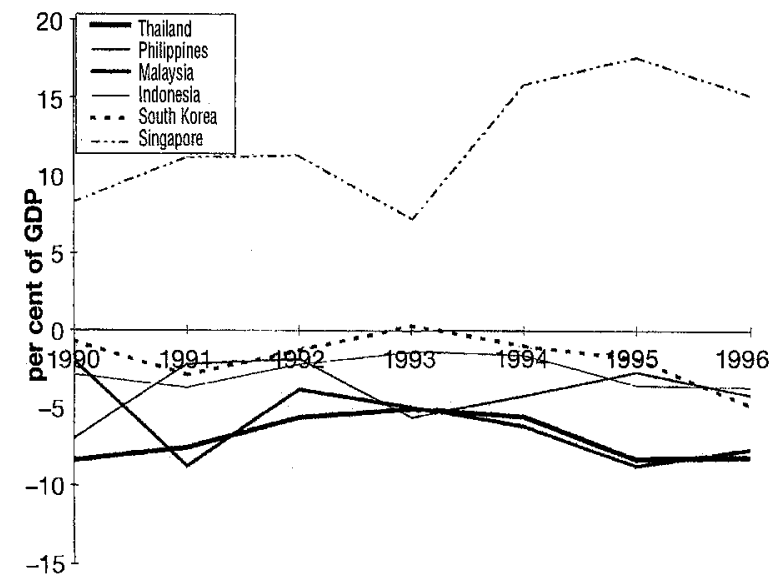

political leadership and the widespread incidence of corruption.

\section{Thailand's Crisis Spreading around South-East Asia}

The Thailand crisis quickly spread to other SouthEast Asian countries such as Malaysia, Indonesia and the Philippines, all of whose currencies came under pressure and fell sharply in value. Like Thailand, these countries were all running high current account deficits, had high levels of foreign debt and were the scene of unhealthy speculation in construction projects and real estate (see Figure 2).

In the period from July to the end of October 1997, the South-East Asian currencies were all devalued more and more against the US dollar, with the Thai baht $(-34 \%)$ and Indonesian rupiah $(-45 \%)$ leading the fall, followed by the Malaysian ringgit $(-26 \%)$ and Philippine peso $(-25 \%)$ (see Figure 3$)^{4}$

The currencies have continued to depreciate, and there is no floor to this trend in sight at the time of writing. While the main initial pressure on the SouthEast Asian currencies came from speculators and from domestic economic actors seeking to hedge

\footnotetext{
2 The baht had been pegged to a basket of currencies dominated by the US dollar, though the Bank of Thailand did permit a certain amount of deviation from the currency's "parity".

${ }^{3}$ Destabilizing speculation may develop as a result of incomplete information and irrational behaviour by market participants. This kind of speculation increases price volatility and is detrimental to the market's efficiency.
} 
their dollar-denominated debts, as time has gone on more long-term factors have played a part in the continued depreciation. In addition to increased credit risk, these include the increasing risk of inflation and the fear that restrictive monetary policies would not be able to stabilize the currencies quickly enough to make up for the loss of confidence in them. The speculative attacks launched against the South-East Asian currencies were subsequently amplified by irrational market behaviour (the domino effect, or the herd instinct), when attention ceased to be paid to the differing underlying structures and fundamental variables in the countries concerned.

Nevertheless, the Singapore dollar only depreciated by about $10 \%$ vis-à-vis the US dollar in the period cited, and the Hong Kong dollar has kept to its US-dollar peg (see Figure 3).

In the normal course of events, when a country's currency depreciates this has a positive impact on its competitiveness provided that its firms are not heavily dependent on imported inputs to produce domestic goods. The Marshall-Lerner criterion, stating when a country's trade balance will improve following devaluation, is not normally met in the short term due to the J-curve effect. ${ }^{5}$ This can also be exacerbated by a fall-off in foreign demand for the country's goods and services in anticipation of a further devaluation of its currency. However, when cumulative devaluations occur in a number of currencies, the impact on international trade can be very damaging, as the "beggarmy-neighbour" policies of the 1930s showed.

The main question now is whether the devaluation of East Asian currencies will persist, and if so, whether any other countries may be forced to adjust their exchange rates. The possibility of a wave of neoprotectionism cannot be ruled out.

\footnotetext{
' These currencies' pegs to a basket of currencies were abandoned in the following sequence: 2nd July for the Thai baht, 11 th July for the Philippine peso, 18th July for the Malaysian ringgit, and 21st July for the Indonesian rupiah.

5 The "J-curve effect" refers to the short-term deterioration in the trade balance following a devaluation as a result of continuing flows of goods with relatively low price elasticities.
}

Franco Ferrari (ed.)

\section{The Unification of International Commercial Law}

\section{Tilburg Lectures}

Since the unification of transnational commercial law promotes certainty of law and, by doing so, the flow of international trade, there is a strong tendency to unify the rules governing situations linked to a plurality of countries. The Tilburg Lectures examine the issue of unification from various points of view (from a scholarly as well as a practitioner's point of view).

They show that unification can be pursued on various levels (a regional, European, versus a global level) by using different means (conventions versus model laws) focusing on different methods (unification of substantive law versus unification of private international law and procedural law) and subjects (from the unification of sales law, factoring law, transport law to the unification of procedural law and arbitration law).

1998, 271 pp., paperback, 68,- DM, 496,- öS, 62,- sFr, ISBN 3-7890-5237-X

(Europäisches Privatrecht, Vol. 4) 
Figure 3

\section{Dollar Exchange Rates of East Asian Currencies}

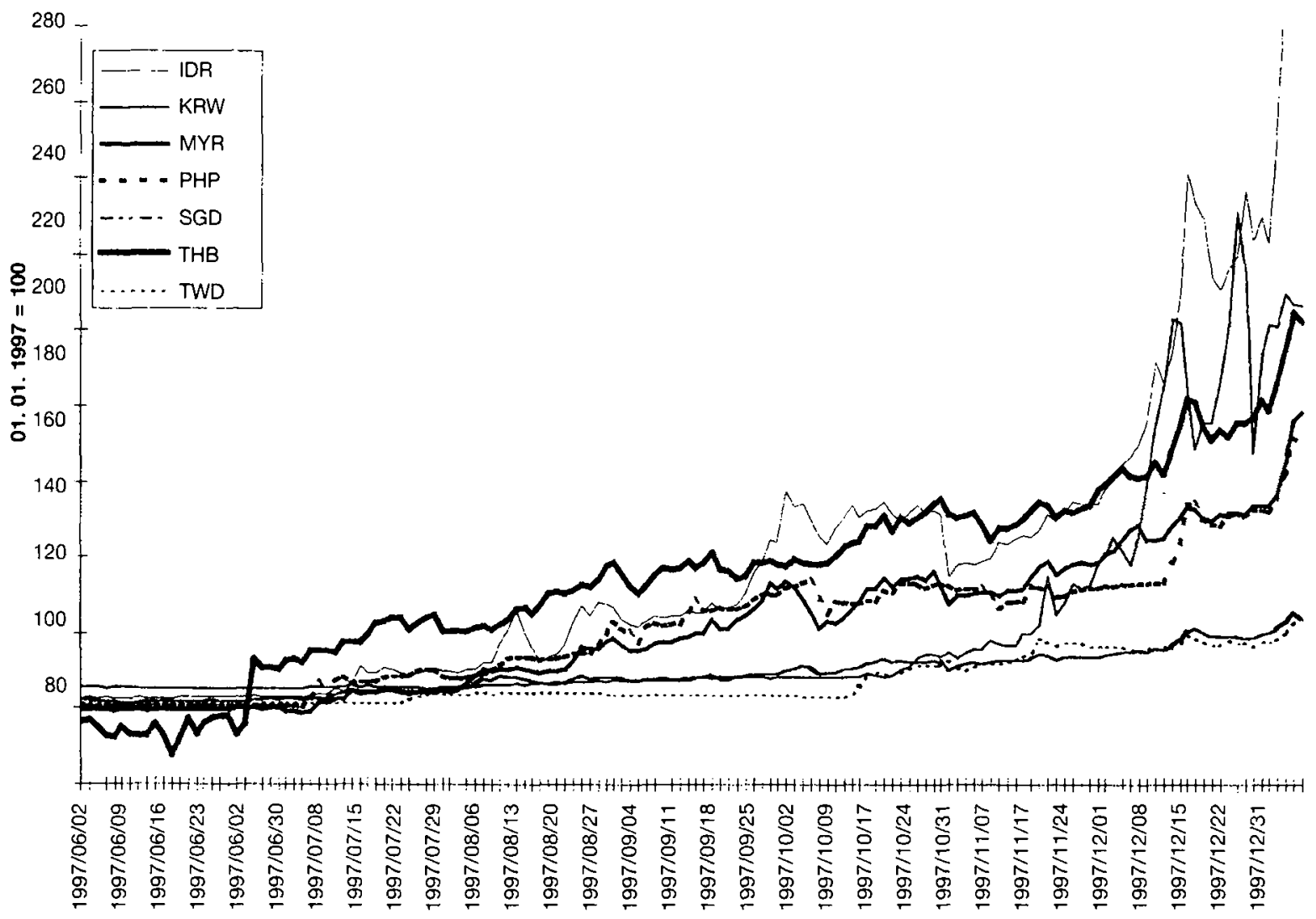

In contrast to Thailand, Indonesia, Malaysia and the Philippines, Hong Kong and Singapore operate primarily as service economies. Hence the devaluation of the former countries' currencies does not have a great deal of influence on Hong Kong's and Singapore's current accounts.

\section{The Hong Kong Crash}

In Hong Kong, too, considerable capital inflows from abroad generated an increase in the domestic credit base and pushed interest rates down. Apart from infrastructure improvements, the foreign funds were also used to finance private consumption and, to a considerable degree, real estate and related construction. These trends fuelled speculation, and property prices soared, putting on $50 \%$ in the space of the previous two years. Given that the banking system had plenty of liquidity, that real property was considered a secure investment, and also given some strong personal connections and corruption in this sector, the credit risk thus accumulated had been ignored. On top of that, there was an increased willingness to enter into risky ventures due to the "moral hazard" effect, because firms thought that they were to be bailed out by the government in case of failure.

Singapore, by contrast, had recognized the risk of a property crisis and taken a number of measures in 1996, following which prices came down.

The excesses in the property market, feelings of insecurity following Hong Kong's reversion to Chinese sovereignty, the South-East Asian currency crisis, and the sheer heights the stock market had reached since 1995, all conspired to produce the Hong Kong crash last autumn. ${ }^{\varepsilon}$

On Thursday, 23rd October 1997, the Hong Kong stock exchange's Hang Seng index fell by $10.41 \%$. Though the index did recover by $6.9 \%$ the following day, the loss over the week as a whole nevertheless came to $16 \%$, by which time the Hang Seng was $33 \%$ down on its all-time high of 7th August 1997. The crash in Hong Kong sent shock-waves to other financial centres, with falls of varying sizes occurring

\footnotetext{
- The Hong Kong crash was chiefly triggered off by negative information, in contrast to the 1987 crash which had purely speculative origins; on this, see G. Aschinger: Börsenkrach und Spekulation - eine ökonomische Analyse, Munich 1995.
} 
Figure 4

\section{Share Indices of East Asian Countries}

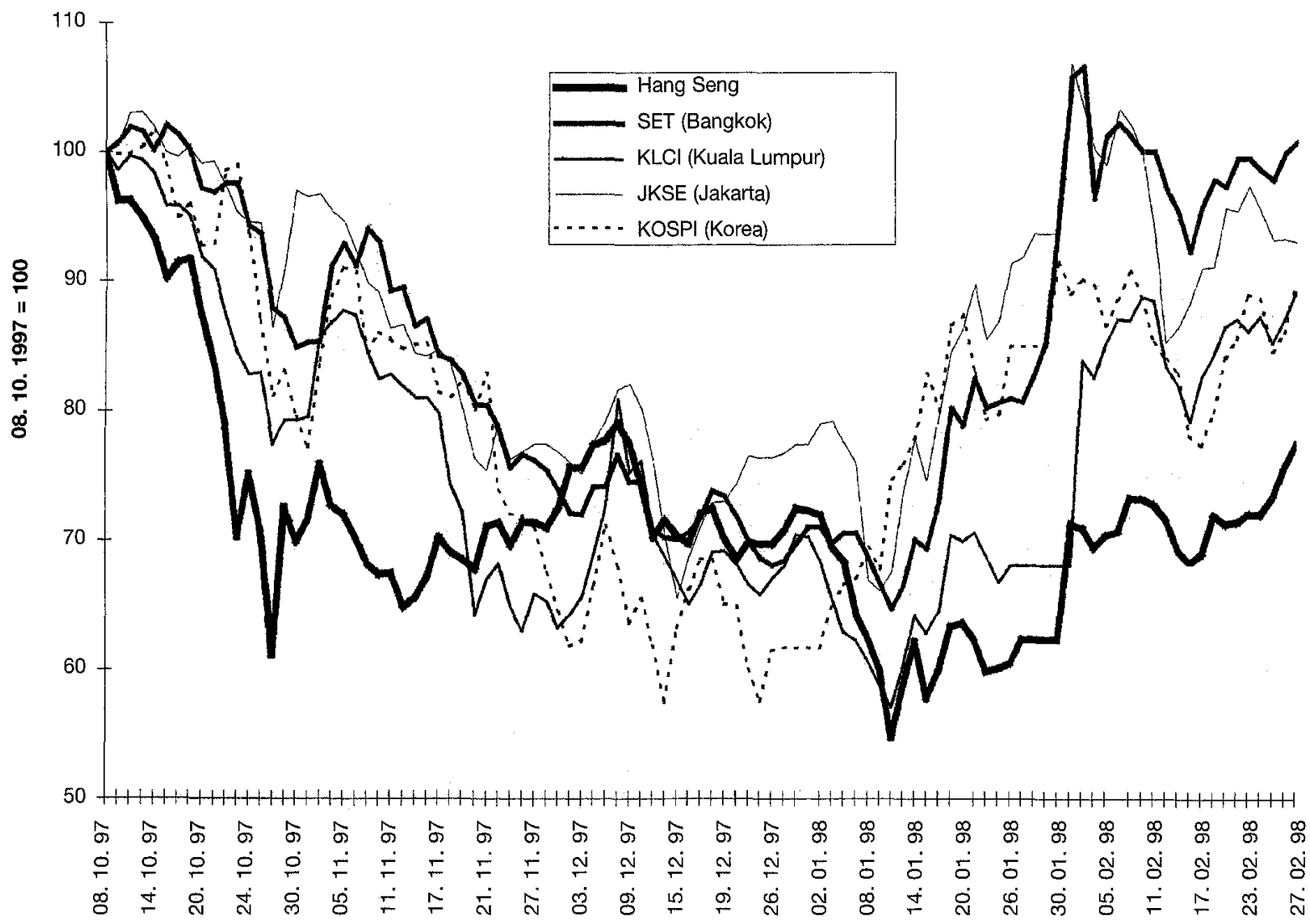

across Europe (DAX -4.7\%; FTSE-100 -3.1\%; CAC$40-3.2 \%$ ), yet slightly smaller ones in the USA, where the Dow Jones Industrial Average fell 2.4\%, and Japan, where the Nikkei index fell $3 \%$.

On Tuesday, 28th October when the Hang Seng dropped by $13.7 \%$, the Hong Kong stock exchange suffered another violent fluctuation, but with an even greater upward one the following day $(+19 \%)$. Also on 28th October, the Dow Jones was up $4.7 \%$, bringing the decline on the NYSE to a halt. Since the week beginning on 20th October (ten years after the 1987 crash), stock markets have tended to be increasingly volatile, as manifested by such factors as a sharp increase in traded volumes. Figure 4 shows the dayby-day movements in the share indices of East Asian stock markets from October 1997 onwards.

Although it was the emergence of negative information (showing altered fundamental variables) which triggered off the Hong Kong crash, the financial markets had been prone to destabilizing speculation for some time, and this may well have amplified the collapse of the Hang Seng index.

\section{The Hong Kong Dollar's Peg to the US Dollar}

The fact that the Hong Kong dollar is the only East Asian currency which has held on to its US\$ peg increases the exposure to speculative attacks, even though Hong Kong has currency reserves of about US $\$ 80$ billion available to defend the US-dollar parity, and China's central bank would be willing to supply further reserves to support the Hong Kong currency if necessary. ${ }^{7}$ Hong Kong operates a currency-board system which guarantees $100 \%$ backing for the Hong Kong dollar in terms of US dollars. The South-East Asian economies had also held their currencies pegged to the US dollar before they were left to float, but in practice they had sometimes deviated from their dollar parities, quite apart from the fact that their holdings of foreign exchange reserves would not have been adequate to mount a credible defence of the exchange rate. Speculators' anticipation that the Hong Kong dollar's peg could be relinquished was

7 The Hong Kong dollar has been pegged to the US dollar since 1983 , at a rate of US\$1 $=$ HK\$ 7.80 . 
heightened by the stock market crash. However, despite the speculative attacks being made on other East Asian currencies the Hong Kong dollar emerged unscathed. It is of great importance to China that Hong Kong's currency-board system should remain in place, since the People's Republic has a vital interest in borrowing from abroad on favourable terms to finance further economic development, and the yuan is not yet properly convertible.

\section{The IMF's Support Activities in South-East Asia}

Most of the countries affected by the South-East Asian crisis, namely Thailand, Indonesia and the Philippines, were promised "bail-out" loan facilities following negotiations with the IMF. These had different credit ceilings and conditions attached, depending on the seriousness of their currency crises and the underlying state of their economies.

Within the scope of the arrangements agreed with the IMF, support programmes were also offered by other countries, notably Japan, the USA and European countries. The purpose behind these support efforts is to prevent countries susceptible to crisis from suffering a collapse in their balance of payments on a scale that could threaten the stability of neighbouring countries and indeed of the international financial system in general.

In August 1997, Thailand was granted an aid package valued at $\$ 17.2$ billion by the IMF and other lenders. ${ }^{8}$ The attached conditions for 1998 include a cut in government expenditure to allow a budget surplus to be achieved even as tax revenues fall. Another condition is that the Bank of Thailand should not allow its currency reserves to fall below a certain minimum (they currently stand at $\$ 24.8$ billion), and yet another is that it must toughen up its lending criteria. The restrictive monetary policy now in place has already led to sharp increases in interest rates.

On 31st October 1997, Indonesia was offered a support programme of $\$ 33$ billion by the IMF and a number of countries. ${ }^{9}$ The promises made by the Indonesian government include that it would break up the country's industrial monopolies, rationalize the ailing banking system, ensure that foreign entities obtain easier access to local financial markets, loosen

\footnotetext{
- The credit line of $\$ 17.2$ billion placed at Thailand's disposa consists of $\$ 3.9$ billion contributed directly by the IMF, $\$ 4$ billion by Japan, a total of $\$ 6$ billion by a group comprising Australia. Hong Kong. Malaysia, Singapore, China, Indonesia and South Korea, \$1.5 billion by the World Bank, and $\$ 1.2$ billion by the Asian Development ¿ank.
}

up the subsidies applied to certain goods, and reduce customs duties. Indonesia declared that it was prepared to close down and possibly liquidate 16 banks.

The Philippines obtained one billion dollars' worth of IMF support to stabilize the peso. Malaysia, on the other hand, has not applied to the Fund for any credit assistance in spite of its high current account deficit, a substantial volume of foreign borrowing and a distressed property sector.

Hong Kong, Singapore and Taiwan do not appear to have been so badly affected by the regional currency crisis.

The aid packages laid on by the IMF, other institutions and governments have attracted a variety of criticisms. First of all, the considerable size of the bridging loans (totalling $\$ 100$ billion for East Asia as a whole), exacerbate the problem of moral hazard. In a market system, private enterprises and government bodies ought to bear their own risks. That requires losses to be internalized, i.e. bankruptcies and all their ensuing consequences ought to be allowed to happen, thus increasing the pressure on everyone in the market to improve efficiency. If there is a general expectation that countries with currency problems will have an international safety-net held out for them, this sends out all the wrong signals and encourages parties to commit themselves to risky projects. It is probably no coincidence that, after credit lines were granted to the East Asian countries, the share price indices in Brazil and Argentina showed strong gains.

The conditions laid down by the IMF are supposed to ensure that the countries affected will improve their economic situations. Yet many of the mistakes that have been made might possibly have been avoided if the institutions had stated from the outset that there would be "no bail out".

Apart from changes in fundamental variables, destabilizing speculation can also play its part in generating international financial crises. In an uncertain currency environment, irrational forms of behaviour such as the "herd instinct" or the "rush for the exit" may play a major part. That not only applies to foreign speculators but also to domestic firms and the public which may take flight into more stable currencies (e.g. the US dollar).

\footnotetext{
- The $\$ 33$-billion allocation was made available as follows: $\$ 10$ billion from the IMF, $\$ 4.5$ billion from the World Bank, $\$ 3.5$ billion from the Asian Development Bank, with second-line credit facilities from Japan ( $\$ 5$ billion), Singapore ( $\$ 5$ billion), the USA ( $\$ 3$ billion). Malaysia ( $\$ 1$ billion) and Australia $(\$ 1$ billion). China may also join this group of supporting countries.
} 


\section{Globalization of Financial Markets}

The various stock exchanges and financial centres around the world are now very strongly interlinked and heavily interdependent. As financial markets have been deregulated and opened up to foreign investors, transaction costs have come down, new derivative financial instruments have been created, computeraided trading systems have been developed and telecommunications technology has progressed, what used to be separate market segments have now merged into just one "world market". One of the results of this is that disruptions occurring in certain countries can rapidly spread to other regions without there necessarily being any causal relationship between the original disruption and the response elsewhere. This is underlined, for example, by the rapid knock-on effect seen to occur from the Hong Kong crash to other financial centres, though with varying degrees of intensity. The high mobility of capital has accelerated the speed at which turbulence on foreign exchange markets is transmitted onward internationally.

\section{The Spread of the Crisis to South Korea}

South Korea faces difficulties similar to those of South-East Asian countries despite its more advanced state of economic development. Over the past 30 years, the country's economy has achieved average annual real growth of $8.6 \%$, and it now ranks eleventh in the world in terms of real GDP. South Korea is known for its major industrial conglomerates (the chaebol) operating in areas such as shipbuilding, automobiles, chemicals and semiconductors. For some years, however, South Korea has been in deficit on its current account, partly because its export volume fell back during the world recession while imports rose substantially (see Figure 2).

As a strong flow of capital came in from abroad, Korean commercial banks had boosted their lending activity without paying sufficient attention to the credit standing of their debtors. The bulk of this lending went into unproductive areas, and transparency was impaired by the complex interlacing among chaebol, and by networks of informal relationships. A lot of Korean firms and banks took to borrowing in US dollars, to take advantage of lower interest rates. In anticipation of the repayments they would need to make on this dollar-denominated debt, they began to step up the trading of Korean won for dollars once the won showed a weakening trend from November 1997 onwards. That only further increased the pressure on the won, which had depreciated by $35 \%$ against the dollar by mid-December (see Figure 3). Between late October and early December 1997, the Bank of Korea's convertible currency reserves fell from $\$ 30.5$ billion to $\$ 23.9$ billion. The government made $\$ 17.9$ billion of these reserves available to commercial banks to allow them to repay their dollar-denominated debt, thus leaving just $\$ 6$ billion in freely available reserves.

\section{IMF Bridging Loans for South Korea}

As it saw the level of foreign debt piling up (it now totals roughly $\$ 120$ billion), the South Korean government tried to arrange loans from other central banks so that it could avoid the tough conditions imposed by the IMF, but it did not succeed because the country's credit standing was no longer adequate. After a number of negotiating rounds with the IMF, an agreement was signed on 3rd December 1997 in which South Korea was granted the largest credit line ever provided by the IMF, for a total of $\$ 57$ billion over a three-year period. ${ }^{10}$

The IMF's conditions as they apply to 1998 are: a $10 \%$ cut in government expenditure, the restriction of GDP growth to a maximum of $2.5-3 \%$, and the reduction of the current account deficit from $\$ 13$ billion to $\$ 5$ billion. The organization also called for a dozen highly indebted Korean banks to be liquidated, and demanded greater transparency among the chaebol conglomerates, together with restructuring measures (including liquidations and also rationalization mergers). In particular, the chaebol were required to cease providing guarantees for their subsidiary companies' debt. The ceiling on equity stakes in Korean firms held by foreign entities was also required to be raised from $26 \%$ to $59 \%$. On top of these more detailed requirements, the IMF called for an increase in taxation, for the pursuit of a restrictive monetary policy which would substantially increase interest rates, and finally for greater labour-market flexibility.

The rate of unemployment in South Korea was $2.4 \%$ in December 1997, but approximately $1 \frac{1}{2}$ million of the current workforce are thought likely to lose their jobs in the wake of the IMF agreement, which would push the unemployment rate up to $7 \%$

\footnotetext{
's The contributions to the $\$ 57$ billion credit package for South Korea were as follows: IMF, $\$ 21$ billion; World Bank, $\$ 10$ billion; Asian Development Bank, $\$ 4$ billion; Japan, $\$ 10$ billion; USA, $\$ 5$ billion; Group of Ten, $\$ 7$ billion.
} 
during 1998. The prospect of this occurring has already given rise to extensive unrest and to strikes by trades unions.

Despite the measures that had been instituted, the won continued its decline against the dollar, partly in anticipation of the dollar-denominated loan repayments which will fall due during 1998, and partly also because of fears that the commercial banking system and the chaebol could collapse altogether. Just a week after the IMF agreement, the won went into "free fall", losing $49 \%$ of its dollar value. The KOSP index also fell by approximately $20 \%$ in the same week, leaving it 50\% lower on its June 1997 level (see Figure 4). A $10 \%$ daily limit on the depreciation of the won soon proved counter-productive and was lifted again on 15th December 1997. South Korea's government then requested the IMF, Japan and the USA to speed up the bridging loan programme, to avoid a meltdown in the foreign exchange and stock markets.

On 23rd December 1997, South Korea's presidentelect, Kim Dae Jung, stated in an interview that the possibility of a debt-repayment moratorium could not be ruled out. That set the won plunging by another $15 \%$, and the KOSP index shed $7.8 \%$. Seeing the persisting drain on confidence, the IMF and a group of countries felt it was necessary to speed up the provision of financial assistance to South Korea, and $\$ 10$ billion in loan finance was released ahead of the scheduled date. Steps were also taken to roll over debt falling due. South Korea's parliament enacted reform legislation conforming to the IMF's conditions, which included independence for the central bank, tax increases, and measures to facilitate structural adjustment. That temporarily calmed the financial markets down. However, the value of the won continued on its downward path in early January 1998, whereupon the government agreed to a toughening of the IMF's conditions, which now assumed real GDP growth in 1998 in the 1-2\% range, along with a $5 \%$ inflation rate, a ceiling on money supply growth of $15 \%$, and convertible currency reserves at an average level of $\$ 8.1$ billion during the year.

On 28th January 1998, the South Korean government and a group of international bankers came to an agreement on the rescheduling and restructuring of

\footnotetext{
"The Morgan/Citicorp/Chase Plan proposed that the South Korean government should make new issues of government bonds worth $\$ 25$ billion. $\$ 10$ billion of the proceeds would have been retained in cash, and the remaining $\$ 15$ billion used to convert Korean commercial bank debt. The bonds' terms to maturity would have ranged from one to 20 years.
}

dollar-denominated debt payable by the country's commercial banks. The plan is to replace short-term by slightly longer-term borrowing (with terms from one to three years). A proportion of the rescheduled debt obligations will be issued with a government guarantee. Once the rescheduling (planned on a voluntary basis) is complete, the plan is that South Korea should replenish its foreign currency reserves by issuing new government bonds. This agreement does not match the "Morgan/Citicorp/Chase" Plan, as the South Korean government was not prepared to issue public in place of private debt paper."

Though foreign debt only amounts to $40 \%$ of the country's GDP, the domestic debt burden totals $180 \%$ of GDP. At least $20 \%$ of the domestic debts are now irrecoverable, so there is a serious danger of banks collapsing due to insufficient liquidity. Consequently, if the other measures already taken do not bear fruit (scaling down and/or takeovers in the banking sector), the Bank of Korea will have to inject liquidity as the lender of last resort.

The Korean crisis also had a telling influence on the foreign exchange and financial markets in South-East Asia. Between mid-1997 and the end of January 1998 , the rupiah depreciated by $80 \%$ against the dollar, while the won, baht and ringgit fell between $45 \%$ and $55 \%$. On one day alone, 8th January 1998 , the rupiah collapsed by no less than $30 \%$. In Figure 3 the exchange rates of East Asian countries are oniy depicted up to December 1997, since the subsequent devaluations of the rupiah would have dwarfed the other exchange rates. The financial markets began to recover in early February, but heightened uncertainty has been reflected in considerable market volatility. Indonesia has been considering establishing a currency board in order to restore confidence in the rupiah. However, a change to this kind of foreignexchange regime would not be credible and this, in the IMF's view, would have the opposite effect to what is desired.

\section{Assessment of the East Asian Crisis}

In spring 1997, the crisis started out in Thailand before spreading to other South-East Asian countries such as Indonesia, Malaysia and the Philippines. Singapore and Hong Kong were also hit, but the two city states' currencies have proven relatively robust. Then in autumn 1997, South Korea was also shaken by a serious currency and economic crisis.

In these countries whose economies had been growing rapidly for many years, various problems 
were manifested that were of their own making, such as increasing current account deficits, property crises, high levels of short-term foreign debt, rapid expansion of domestic credit, a lack of efficient risk management, and inadequate supervision of commercial banks. During long periods of economic growth, capital inflows from abroad are necessary to meet the high funding needs for industrial development while savings levels, for the time being, remain low. Despite increasing exports, the countries concerned nevertheless developed current account deficits due to high demand for imported capital goods and the need to service foreign debt, and the deficits were covered by net imports of capital. The fact that the countries' currencies were pegged to the dollar boosted the confidence of foreign investors. The large inflows of foreign exchange led to an increase in domestic money supply and kept interest rates down. Banks strongly increased their lending activity, most of which was concentrated in "non-productive" areas such as the property market. Because they did not practice adequate risk management, they allowed "bad" loans to pile up, and when demand unaccustomedly fell back many business ventures became insolvent and large numbers of jobs were lost.

A significant underlying reason for the East Asian crisis is the "moral hazard" effect. The structure of these countries' economies involves an intricate network of cross shareholdings and personal contacts. A lot of firms had undertaken unduly high risks, in the hope that the state would back them if they faced the threat of bankruptcy (implicit government guarantee). Under these circumstances, firms were able to pocket the profits they earned on risky ventures, while saddling the general public with any substantial losses they incurred. This "risk asymmetry" brought with it the danger of a systemic crisis as greater and greater risks were taken. On the next level up, both governments and large companies in the East Asian economies assumed that international organizations, particularly the IMF and World Bank, would be quick to "bail them out" with bridging loans as they already had done in Mexico's case. That raised the willingness to accept risks far beyond the optimum level.

Implicit government guarantees and international aid programmes distort risk patterns, and ought therefore to be implemented with great restraint, to keep moral hazard as low as possible. 12. Cf., e.g., M. Haq, I. Kaul, I. Grunberg: The Tobin Tax, New
York 1996.
The tremendous loss of confidence in East Asian countries generated turbulence on the foreign exchanges and pushed up their interest rates strongly. Speculation against their domestic currencies was further fuelled as their own nationals with dollardenominated debts took flight in hard currencies.

To stave off the threat of whole economies collapsing, or at least of debt moratoria being declared, the IMF and creditor nations offered support in the shape of new loans. Foreign bank consortia offered firms in these countries debt-rescheduling packages, allowing them to transform short-term into longer-term obligations.

It is only natural that the western industrial nations and Japan have an interest in halting East Asia's economic slide, as their own exports to the region play a significant part in securing jobs for the long haul. On the other hand, the huge devaluations of East Asian currencies pose a threat to the western industrial countries' competitiveness.

The assistance provided by the IMF had the usual kind of conditions attached to ensure that financial structures in the countries concerned were reorganized. Choking back economic growth, while forcing domestic industrial groups to divest some of their interests in one another and to rationalize, will lead to some marked increases in unemployment. And although the danger of the East Asian crisis worsening still further now appears to have been banished for the time being, the financial markets remain highly volatile.

Globalization means that different economies are increasingly interdependent, allowing disruptions to be quickly transmitted from one place to another. The only way of mitigating the tendency towards instability is to set up multilateral agreements applying appropriate conditions, particularly to financial markets. Alongside fundamental imbalances, a large amount of destabilizing speculation is also in evidence on the foreign exchanges, taking irrational forms such as the herd instinct and self-fulfilling prophecies. Not only does the overall economic community need to look at ways of improving risk management (in respect of both credit and market risks), but it should also examine the pros and cons of introducing a "Tobin tax" on foreign exchange transactions. ${ }^{12}$ Naturally, at the end of the day, whatever sensible precautions are taken at both national and international levels to limit the occurrence of financial and currency crises, it will never be possible to totally rule them out, simply because of human nature being what it is. 